This document was prepared in conjunction with work accomplished under Contract No. DE-AC09-96SR18500 with the U. S. Department of Energy.

\title{
DISCLAIMER
}

This report was prepared as an account of work sponsored by an agency of the United States Government. Neither the United States Government nor any agency thereof, nor any of their employees, nor any of their contractors, subcontractors or their employees, makes any warranty, express or implied, or assumes any legal liability or responsibility for the accuracy, completeness, or any third party's use or the results of such use of any information, apparatus, product, or process disclosed, or represents that its use would not infringe privately owned rights. Reference herein to any specific commercial product, process, or service by trade name, trademark, manufacturer, or otherwise, does not necessarily constitute or imply its endorsement, recommendation, or favoring by the United States Government or any agency thereof or its contractors or subcontractors. The views and opinions of authors expressed herein do not necessarily state or reflect those of the United States Government or any agency thereof. 


\section{INITIAL SULFATE SOLUBILITY STUDY FOR SLUDGE BATCH 4 (SB4)}

T.H. Lorier

I.A. Reamer

R.J. Workman

April 2005

Immobilization Technology Section Savannah River National Laboratory Aiken, SC 29808
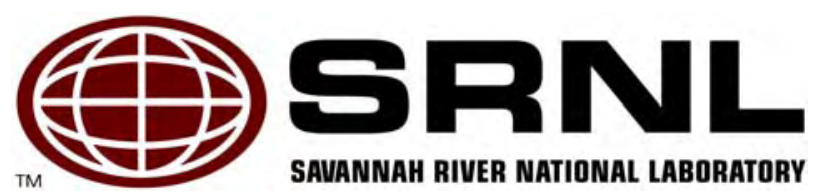


\section{DISCLAIMER}

This report was prepared by Westinghouse Savannah River Company (WSRC) for the United States Department of Energy under Contract No. DE-AC09-96SR18500 and is an account of work performed under that contract. Neither the United States Department of Energy, nor WSRC, nor any of their employees makes any warranty, expressed or implied, or assumes any legal liability or responsibility for the accuracy, completeness, or usefulness, of any information, apparatus, or product or process disclosed herein or represents that its use will not infringe privately owned rights. Reference herein to any specific commercial product, process, or service by trademark, name, manufacturer or otherwise does not necessarily constitute or imply endorsement, recommendation, or favoring of same by WSRC or by the United States Government or any agency thereof. The views and opinions of the authors expressed herein do not necessarily state or reflect those of the United States Government or any agency thereof.

\section{Printed in the United States of America}

Prepared For

U.S. Department of Energy 
Key Words: Sulfate solubility, $\mathrm{SO}_{4}{ }^{=}$limit, Sludge Batch 4 (SB4)

Retention: Permanent

\section{INITIAL SULFATE SOLUBILITY STUDY FOR SLUDGE BATCH 4 (SB4)}

T.H. Lorier

I.A. Reamer

R.J. Workman

April 2005 


\section{REVIEWS AND APPROVALS}

\section{AUTHOR(S):}

\section{Troy 1. Jovien}

T.H. Lorier, Immobilization Technology Section

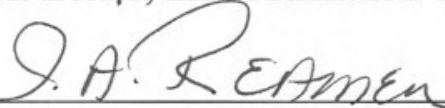

I.A. Reamer, Immobilization Technology Section

R.q.Workman

R.J. Workman, Immobilization Technology Section
$5-19-2005$

Date

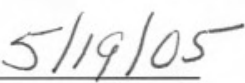

Date

\section{TECHNICAL REVIEWERS:}

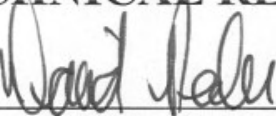

D.K. Peeler, Immobilization Technology Section

$$
\text { C. D. Dlenman }
$$

C.C. Herman, Immobilization Technology Section
5-20-05

Date

$5-19-25$

Date

\section{APPROVERS}

En fretzichos

E. W. Holtzscheiter, Manager, Immobilization Technology Section Shand forlanc,

S. L. Marra, Manager, Glass Formulation \& Process Development

E. Occhipinti, Manager, DWPF Process Engineering
$5-19-05$

Date $5 / 23 / 05$ Date

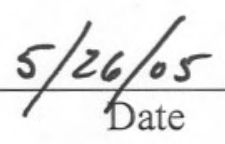




\section{EXECUTIVE SUMMARY}

The objective of this task is to provide the Defense Waste Processing Facility (DWPF) of the Savannah River Site (SRS) with an assessment of the viability of using the current $0.6 \mathrm{wt} \% \mathrm{SO}_{4}{ }^{=}$limit (in glass) and/or the possibility of increasing the $\mathrm{SO}_{4}{ }^{2}$ solubility limit to account for anticipated sulfur concentrations in Sludge Batch 4 (SB4). The $0.6 \mathrm{wt} \% \mathrm{SO}_{4}{ }^{\circ}$ limit was implemented for processing of Frit 418 - Sludge Batch 3 (SB3) to avoid the formation of sulfate inclusions in the glass and/or the formation of a molten sulfate-rich phase on the melt pool in the DWPF melter. The presence of such a phase on the surface of the melt pool increases corrosion rates of melter components, enhances the potential for steam excursions in a slurry-fed waste glass melter, and creates the potential for undesirable current paths that could deplete energy delivered to the melter due to the electrical conductivity of the molten salt layer.

This suite of sulfate-solubility tests began by testing the 1200 -canister, $2^{\text {nd }}$ transfer case for SB4 (as defined by Lilliston and Shah, 2004) - based on this being the most conservative (having the highest predicted viscosity when coupled with specific frits, it could potentially have the greatest impact on $\mathrm{SO}_{4}{ }^{=}$ solubility) blending scenario of SB4 with the heel of SB3 for $\mathrm{SO}_{4}{ }^{\overline{ }}$ solubility. Frits 320 and 418 were tested with SB4 and the tests indicated that at the current $\mathrm{SO}_{4}{ }^{-}$limit (in glass) and the tested waste loadings (30\% and 40\%), neither Frit 320 nor Frit 418 could be utilized with SB4 (for the 1200-canister, $2^{\text {nd }}$ transfer case composition originally provided). More specifically, $\mathrm{SO}_{4}{ }^{=}$was observed on the surface with the SB4 composition and Frit 320 at $40 \%$ waste loading (WL) and $0.6 \mathrm{wt} \% \mathrm{SO}_{4}{ }^{{ }}$, and with Frit 418 at $30 \%$ and $40 \% \mathrm{WL}$ and $0.5 \mathrm{wt} \% \mathrm{SO}_{4}{ }^{2}$. As alternative frits were being developed - Frits 447, 448, and 449, that contained $\mathrm{CaO}$ and/or $\mathrm{V}_{2} \mathrm{O}_{5}$ to enhance $\mathrm{SO}_{4}{ }^{=}$solubility based on suggestions of previous studies - testing began of the 1100-canister, $1^{\text {st }}$ transfer case for SB4 (from Lilliston, 2005), which is the baseline flowsheet for the DWPF. The results of the study with the revised compositions have indicated that the $\mathrm{SO}_{4}{ }^{2}$ solubility limit in the DWPF of $0.6 \mathrm{wt} \%$ can be applicable for the 1100 -canister, $1^{\text {st }}$ transfer case of SB4 for certain frits. Five frits were tested in closed-crucible studies - Frits 320, 418, 447, 448, and 449. Tests with Frit 418 showed that $\mathrm{SO}_{4}{ }{ }$ was apparent on the glass surface of tests at $40 \% \mathrm{WL}$ and $0.6 \mathrm{wt} \%$ $\mathrm{SO}_{4}{ }^{2}$. No salt layer formation was evident in any test (30\% or $40 \%$ WL) with Frits 320,447 , 448, or 449 until $\mathrm{SO}_{4}{ }^{=}$concentrations of $0.8 \mathrm{wt} \%$ were targeted. The crucible tests of this study and model predictions (from Jantzen and Smith, 2004) indicated that the $\mathrm{SO}_{4}{ }^{~}$ solubility limit for SB4 with those four frits would be similar. However, even with the additions of $\mathrm{CaO}$ and $\mathrm{V}_{2} \mathrm{O}_{5}$, the solubility of $\mathrm{SO}_{4}{ }^{=}$ was not greatly enhanced by Frits 447, 448, and 449 over Frit 320 for the 1100 -canister, $1^{\text {st }}$ transfer case.

The following recommendation is made regarding the $\mathrm{SO}_{4}{ }^{*}$ solubility limit for SB4 in the DWPF:

- Reinvestigate the solubility of $\mathrm{SO}_{4}{ }^{=}$for SB4 once the final blending and/or washing strategies for SB4 are determined - based on the decisions for the inclusion of Tank 4 and the exact volume and composition of the $\mathrm{Np}$ stream - in order to determine if the current $\mathrm{SO}_{4}{ }^{2}$ solubility limit $(0.6$ $\mathrm{wt} \% \mathrm{SO}_{4}{ }^{\circ}$ ) in the DWPF needs to be increased for the processing of SB4. 


\section{TABLE OF CONTENTS}

EXECUTIVE SUMMARY

LIST OF FIGURES

LIST OF TABLES

LIST OF ACRONYMS

1.0 INTRODUCTION AND BACKGROUND

2.0 APPROACH and results

2.1 1200-Canister, $2^{\text {nd }}$ Transfer Scenario

2.1.1 Frit 320 Tests

2.1.2 Frit 418 Tests

2.2 1100-Canister, $1^{\text {st }}$ Transfer Scenario

3.0 DISCUSSION

4.0 CONCLUSIONS

$\mathrm{V}$

5.0 RECOMMENDATIONS/PATH FORWARD

6.0 REFERENCES

vii

vii

viii

1

1

2

3

5

5

8

9

10

11 


\section{LIST OF FIGURES}

Figure 2-1. Photos of crucible tests of Frit 320 with SB4 1200-canister, $2^{\text {nd }}$ transfer . . .4

\section{LIST OF TABLES}

Table 2-1. Elemental composition of SB4 sludge -1200 -canister, $2^{\text {nd }}$ transfer scenario .......................... 2

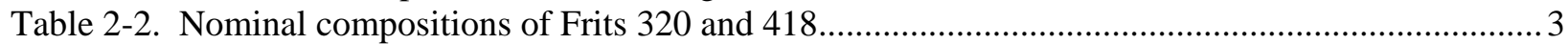

Table 2-3. Summary of closed-crucible tests for the 1200 -canister, $2^{\text {nd }}$ transfer scenario.......................... 4

Table 2-4. Elemental composition of SB4 sludge - 1100-canister, $1^{\text {st }}$ transfer scenario............................. 5

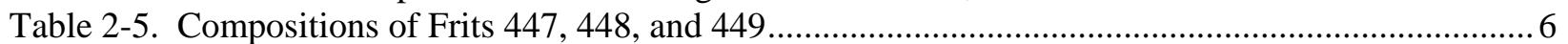

Table 2-6. Summary of closed-crucible tests for the 1100 -canister, $1^{\text {st }}$ transfer scenario.......................... 7

Table 2-7. Measured $\mathrm{SO}_{4}{ }^{2}$ compositions (in glass) of studies for the 1100 -canister, $1^{\text {st }}$ transfer scenario .. 7

Table 3-1. Approximated $\mathrm{SO}_{4}{ }^{=}$solubilities (at saturation) of tested frits with the 1100 -canister, $1^{\text {st }}$ transfer

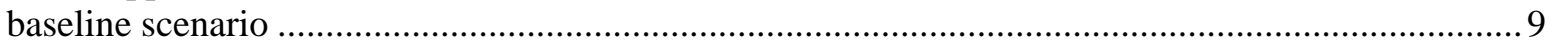




\section{LIST OF ACRONYMS}

$\begin{array}{ll}\text { CBU } & \text { Closure Business Unit } \\ \text { DWPF } & \text { Defense Waste Processing Facility } \\ \text { MAR } & \text { Measurement Acceptability Region } \\ \text { PCCS } & \text { Product Composition Control System } \\ \text { SB1A } & \text { Sludge Batch 1A } \\ \text { SB1B } & \text { Sludge Batch 1B } \\ \text { SB2 } & \text { Sludge Batch 2 } \\ \text { SB3 } & \text { Sludge Batch 3 } \\ \text { SB4 } & \text { Sludge Batch 4 } \\ \text { SME } & \text { Slurry Mix Evaporator } \\ \text { SRAT } & \text { Sludge Receipt and Adjustment Tank } \\ \text { SRS } & \text { Savannah River Site } \\ \text { WL } & \text { Waste Loading }\end{array}$




\subsection{INTRODUCTION AND BACKGROUND}

The Defense Waste Processing Facility (DWPF) is presently vitrifying Sludge Batch 3 (SB3) and preparing to process Sludge Batch 4 (SB4). Based on a compositional analysis of SB3 (Lilliston and Elder, 2003), it was determined that the total amount of $\mathrm{SO}_{4}{ }^{\circ}$ in $\mathrm{SB} 3$ would be higher than the sulfate processed in any of the previous DWPF sludge batches (SB1A, SB1B, or SB2) and, when processed, would exceed the Product Composition Control System (PCCS) Slurry Mix Evaporator (SME) limit for $\mathrm{SO}_{4}{ }^{2}$. The sulfate comes from the addition of ferrous sulfamate and hydroxylamine sulfate during Savannah River Site's (SRS) solvent extraction processes to purify U, Pu, and Np. Targeting a lesswashed sludge for SB3, as well as the addition of excess Np-based streams directly from H-canyon after the sludge had already been prepared, resulted in increased levels of $\mathrm{SO}_{4}{ }^{2}$ in the sludge. For all previous sludge batches (SB1A, SB1B, or SB2) the sulfate solubility limit was $0.4 \mathrm{wt} \% \mathrm{SO}_{4}{ }^{{ }^{2}}$ in glass (based on two references by Bickford et al. $(1986,1990))$. However, because of the increased $\mathrm{SO}_{4}{ }^{=}$levels in SB3 and the addition of the Np-based stream, testing was conducted to determine if the sulfate solubility limit could be increased to prevent additional washing of SB3 and accept a significant portion of the Np stream. Based on sealed-crucible studies, the limit was raised to $0.6 \mathrm{wt} \% \mathrm{SO}_{4}{ }^{=}$in glass for the SB3/Frit 418 system (Peeler et al., 2004a).

The $\mathrm{SO}_{4}{ }^{2}$ limit in PCCS was implemented to avoid the formation of sulfate inclusions and/or the formation of a molten sulfate-rich phase on the melt pool in the DWPF melter. The presence of this low viscosity melt phase on the surface of the melt pool increases corrosion rates of the materials of construction (off-gas, refractories [primarily at the melt line], and top head components (e.g., thermowells, level dip tube and upper electrodes)). The molten salt layer is purported to enhance the potential for steam explosions in waste glass melters that are slurry fed (Schumacher et al. 1991). In addition, there is potential for undesirable current paths that could deplete energy delivered to the melter due to the electrical conductivity of the molten salt layer.

As the vitrification of SB3 continues, the DWPF is preparing for SB4 and is planning to begin its processing in late 2006 or early 2007. The final composition of SB4 is unknown, as the blending and/or washing strategies are still being contemplated. It should be noted that the contents of Tanks 5, 6, 7, 8, and 11 (which will be transferred to Tank 51) along with plutonium and neptunium solutions from F- and H-Canyons, and possibly material from Tank 4 will comprise SB4 (Shah et al., 2005). In order to estimate the range of plausible compositions of SB4, a parametric study was done by differing the amounts of each tank (only Tanks 4, 5, 6, and 11 were varied since they contain the bulk of the SB4 material) to be blended, as well as scenarios where Tanks 4,5 , and 6 were not included. The study also considered different blending points of SB4 with SB3 (Lilliston, 2005). For the sulfate solubility studies of this report, the 1200 -canister, $2^{\text {nd }}$ transfer composition was specified by Lilliston and Shah (2004), and the 1100 -canister, $1^{\text {st }}$ transfer composition was specified by Lilliston (2005). The intent of these initial sealed-crucible studies and this report is not to set or define a new sulfate solubility limit for SB4, but to supply guidance to the Closure Business Unit (CBU) on washing and blending strategies, determine if the $\mathrm{SO}_{4}=$ limit can or should be increased for SB4, and provide insight into the frit selection process.

\subsection{APPROACH AND RESULTS}

Sulfate solubility of any sludge batch system is a function of the overall glass composition, which is determined by the sludge composition, frit composition, and waste loading (WL). The approach used to assess the $\mathrm{SO}_{4}{ }^{=}$solubility limit for SB4 utilized sealed-crucible tests. Sealed crucibles create a closed system where a high partial pressure of $\mathrm{SO}_{2}(\mathrm{~g})$ in the vapor space forces as much of the $\mathrm{SO}_{4}{ }^{=}$species to remain in the glass as possible - sulfate vaporization is inhibited (Jantzen et al., 2004). Two series of 
sealed-crucible scale tests were performed. The first was based on the 1200 -canister, $2^{\text {nd }}$ transfer scenario for the composition of SB4 (as defined by Lilliston and Shah, 2004). The second series was based on the 1100-canister, $1^{\text {st }}$ transfer scenario (as defined by Lilliston, 2005). Some of the differences between the specific compositions of this study included higher $\mathrm{Al}$ and lower $\mathrm{Ca}, \mathrm{Fe}, \mathrm{Mg}$, and $\mathrm{Ni}$ in the 1200-canister, $2^{\text {nd }}$ transfer composition. The 1100 and 1200 canisters refer to the number of DWPF equivalent canisters to be produced before SB4 is transferred to Tank 40 (Lilliston and Shah, 2004). All testing was based on the use of reagent grade (or batch) chemicals ${ }^{1}$ targeting specific glass compositions based on a range of WLs (30-40\%), and a range of sulfate concentrations (0-0.9 wt\%). The WL range and the frits tested were based on model-based assessments performed by Peeler and Edwards (2005a) using the initial composition projections provided by Lilliston and Shah (2004) and a subsequent model-based assessment by Peeler and Edwards (2005b) using the later projections supplied by Lilliston (2005). In those studies, projected operating windows were defined based on model predictions using the Measurement Acceptability Region (MAR) criteria as defined by Brown et al. (2002) for SME acceptability. Both tested WLs (30\% and 40\%) were within all projected operating windows for the SB4-based systems. It should be noted that the model-based assessments were performed in the absence of projected $\mathrm{SO}_{4}{ }^{2}$ concentrations.

\subsection{0-Canister, $2^{\text {nd }}$ Transfer Scenario}

The compositional options listed by Lilliston and Shah (2004) fell into three categories: 1) SB4-only, 2) 1100 equivalent canisters, and 3) 1200 equivalent canisters. Previous results (Jantzen and Smith, 2004; Peeler et al., 2004a) suggest that $\mathrm{SO}_{4}{ }^{=}$solubility increases with increased alkali content (or decreasing predicted viscosity). Preliminary assessments of the twenty SB4 compositions indicated that the sludge/frit combination with the highest viscosity was 1200 -canister, $2^{\text {nd }}$ transfer case with Frit 418 (Peeler and Edwards, 2005a). To be conservative (in terms of predicted viscosity), the first series of tests in the sulfate solubility study for SB4 was the 1200 -canister, $2^{\text {nd }}$ transfer case for SB4. The elemental composition of SB4 for this scenario, as stated by Lilliston and Shah (2004) is listed in Table 2-1 (no $\mathrm{SO}_{4}{ }^{=}$levels reported).

Table 2-1. Elemental composition of SB4 sludge - 1200 -canister, $2^{\text {nd }}$ transfer scenario

\begin{tabular}{|c|c|}
\hline Elementals & $\begin{array}{c}\text { 1200-Canister, } \\
\mathbf{2}^{\text {nd }} \text { Transfer Scenario }\end{array}$ \\
\hline $\mathrm{Al}$ & 13.410 \\
\hline $\mathrm{B}$ & 0.000 \\
\hline $\mathrm{Ba}$ & 0.150 \\
\hline $\mathrm{Ca}$ & 0.920 \\
\hline $\mathrm{Ce}$ & 0.168 \\
\hline $\mathrm{Cr}$ & 0.178 \\
\hline $\mathrm{Cs}$ & 0.000 \\
\hline $\mathrm{Cu}$ & 0.064 \\
\hline $\mathrm{Fe}$ & 16.403 \\
\hline $\mathrm{K}$ & 1.104 \\
\hline $\mathrm{La}$ & 0.073 \\
\hline $\mathrm{Li}$ & 0.000 \\
\hline $\mathrm{Mg}$ & 0.798 \\
\hline $\mathrm{Mn}$ & 4.242 \\
\hline
\end{tabular}

\footnotetext{
${ }^{1}$ Previous testing (Peeler et al., 2004a) has shown that the use of batch chemicals provides a conservative evaluation of $\mathrm{SO}_{4}{ }^{=}$ solubility as there is minimal volatility (compared to use of Sludge Receipt Adjustment Tank (SRAT) product).
} 


\begin{tabular}{|c|c|}
\hline Mo & 0.000 \\
\hline $\mathrm{Na}$ & 16.890 \\
\hline $\mathrm{Nb}$ & 0.000 \\
\hline $\mathrm{Ni}$ & 3.485 \\
\hline $\mathrm{Pb}$ & 0.063 \\
\hline $\mathrm{Si}$ & 1.200 \\
\hline $\mathrm{Th}$ & 0.032 \\
\hline $\mathrm{Ti}$ & 0.011 \\
\hline $\mathrm{U}$ & 7.512 \\
\hline $\mathrm{Y}$ & 0.000 \\
\hline $\mathrm{Zn}$ & 0.096 \\
\hline $\mathrm{Zr}$ & 0.212 \\
\hline
\end{tabular}

No Th or $\mathrm{U}$ were added to the batches and all other components were renormalized for the batching process. Peeler and Edwards (2005a) identified Frits 320 and 418 as candidates that had operating windows at the MAR for this SB4 system ranging from 25\% to $43 \% \mathrm{WL}$. For the purposes of this sludge batch system and study, these two frits are relatively bounding in terms of $\mathrm{Na}_{2} \mathrm{O}$ concentration ( 8 and 12 wt\%). The nominal compositions of Frits 320 and 418 are shown in Table 2-2.

Table 2-2. Nominal compositions of Frits 320 and 418

\begin{tabular}{||l|c|c||}
\hline Oxide & Frit 320 & Frit 418 \\
\hline $\mathrm{B}_{2} \mathrm{O}_{3}$ & 8 & 8 \\
\hline $\mathrm{Li}_{2} \mathrm{O}$ & 8 & 8 \\
\hline $\mathrm{Na}_{2} \mathrm{O}$ & 12 & 8 \\
\hline $\mathrm{SiO}_{2}$ & 72 & 76 \\
\hline
\end{tabular}

The sealed-crucible tests with these two frits and the 1200-canister sludge targeted $\mathrm{SO}_{4}{ }^{=}$levels in the glass of $0,0.4,0.5,0.6,0.7,0.8$, and $0.9 \mathrm{wt} \%$, at $30 \%$ and $40 \% \mathrm{WL}$. Once batched each crucible was sealed (using a nepheline gel) and placed in a furnace at $1150^{\circ} \mathrm{C}$ for 4 hours. Visual observations were made once the crucibles were cool and the sealed lids were removed. The primary visual observation was the formation of a yellow salt layer on the surface of the glass which indicated that not all of the $\mathrm{SO}_{4}{ }^{{ }}$was soluble (see Figure 2-1 for examples). In addition to visual observations, samples of each glass were submitted to the Mobile Lab (ML) for compositional analysis and to assess $\mathrm{SO}_{4}{ }$ retention in the glass.

\subsubsection{Frit 320 Tests}

For the Frit 320 tests, $\mathrm{SO}_{4}{ }{ }$ was not evident on the surface of the final glass until $0.7 \mathrm{wt} \%\left(\mathrm{SO}_{4}{ }{ }\right.$ along the melt line) at 30\% WL. At 40\% WL for Frit 320, $\mathrm{SO}_{4}{ }^{\circ}$ was apparent along the melt line at $0.6 \mathrm{wt} \%$, along with a $\mathrm{SO}_{4}{ }^{\circ}$ scum layer across the entire surface. Sulfate retention was expected to be greater at $40 \% \mathrm{WL}$ since it has a lower viscosity than $30 \% \mathrm{WL}-\mathrm{SO}_{4}{ }^{=}$solubility increases with decreasing viscosity (Jantzen and Smith, 2004). However, SB4 has a high concentration of $\mathrm{Al}_{2} \mathrm{O}_{3}$ and Sullivan et al. (1995) indicated that $\mathrm{SO}_{4}{ }{ }$ solubility decreases with increasing $\mathrm{Al}_{2} \mathrm{O}_{3}$ content (less $\mathrm{SO}_{4}{ }^{=}$solubility as WL increases). Photos of a few sealed-crucible tests with Frit 320 appear in Figure 2-1, and a table of the visual observations of all the tests with Frit 320 appears in Table 2-3. In Figure 2-1, the first number in each photo is the frit, the second is the $\mathrm{WL}$, and the third is the targeted $\mathrm{SO}_{4}{ }^{=} \mathrm{wt} \%$. For example, 320-30-0.5 indicates that this glass is based on Frit 320, targeted a WL of $30 \%$, and targeted a $\mathrm{SO}_{4}{ }^{{ }}$content of 0.5 wt $\%$. 

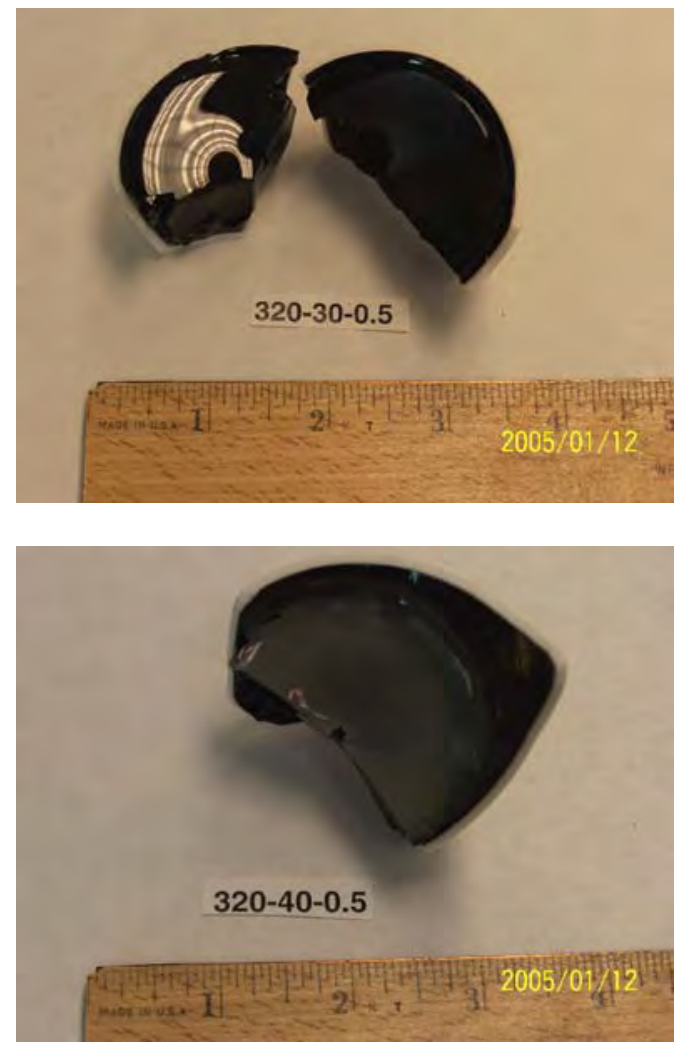

Examples of glasses with no $\mathrm{SO}_{4}{ }{ }$ on the surface (all $\mathrm{SO}_{4}{ }{ }$ in the glass)
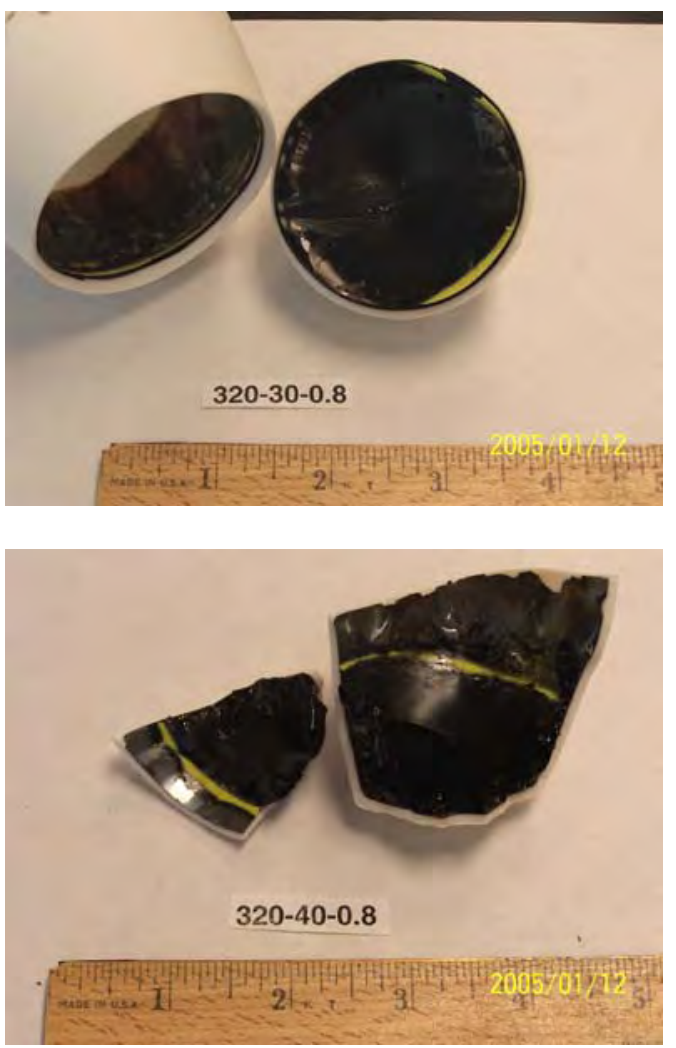

Examples of glasses with $\mathrm{SO}_{4}{ }^{2}$ (yellow) on the surface ( $\mathrm{SO}_{4}{ }^{\circ}$ along melt line and not in glass)

Figure 2-1. Photos of crucible tests of Frit 320 with SB4 1200-canister, $2^{\text {nd }}$ transfer $^{2}$

Table 2-3. Summary of closed-crucible tests for the 1200 -canister, $2^{\text {nd }}$ transfer scenario

\begin{tabular}{|c|c|c|c|c|c|c|c|c|}
\hline Frit & WL & $\begin{array}{c}0.0 \mathrm{wt} \% \\
\mathrm{SO}_{4}{ }^{=} \\
\text {target }\end{array}$ & $\begin{array}{c}0.4 \mathrm{wt}^{\mathrm{w}} \% \\
\mathrm{SO}_{4}{ }^{=} \\
\text {target }\end{array}$ & $\begin{array}{c}0.5 \mathrm{wt}^{0} \% \\
\mathrm{SO}_{4}{ }^{=} \\
\text {target }\end{array}$ & $\begin{array}{c}0.6 \mathrm{wt} \% \\
\mathrm{SO}_{4}{ }^{=} \\
\text {target }\end{array}$ & $\begin{array}{c}0.7 \mathrm{wt} \% \\
\mathrm{SO}_{4}{ }^{=} \\
\text {target }\end{array}$ & $\begin{array}{c}0.8 \mathrm{wt} \% \\
\mathrm{SO}_{4}{ }^{=} \\
\text {target }\end{array}$ & $\begin{array}{c}0.9 \mathrm{wt}^{\mathrm{O}} \% \\
\mathrm{SO}_{4}{ }^{=} \\
\text {target }\end{array}$ \\
\hline \multirow[t]{2}{*}{320} & $30 \%$ & $\begin{array}{c}\text { metallic } \\
\text { haze }\end{array}$ & $\begin{array}{c}\text { metallic } \\
\text { haze }\end{array}$ & $\begin{array}{c}\text { metallic } \\
\text { haze }\end{array}$ & $\begin{array}{c}\text { metallic } \\
\text { haze }\end{array}$ & $\mathrm{SO}_{4}{ }^{=}$ & $\mathrm{SO}_{4}{ }^{=}$ & $\mathrm{SO}_{4}{ }^{=}$ \\
\hline & $40 \%$ & $\begin{array}{c}\text { metallic } \\
\text { haze }\end{array}$ & $\begin{array}{c}\text { metallic } \\
\text { haze }\end{array}$ & $\begin{array}{c}\text { metallic } \\
\text { haze }\end{array}$ & $\mathrm{SO}_{4}{ }^{=}$ & $\mathrm{SO}_{4}{ }^{=}$ & $\mathrm{SO}_{4}{ }^{=}$ & $\mathrm{SO}_{4}{ }^{=}$ \\
\hline \multirow[t]{2}{*}{418} & $30 \%$ & clean & clean & $\mathrm{SO}_{4}{ }^{=}$ & $\mathrm{SO}_{4}=$ & $\mathrm{SO}_{4}{ }^{=}$ & $\mathrm{SO}_{4}{ }^{=}$ & $\mathrm{SO}_{4}{ }^{=}$ \\
\hline & $40 \%$ & $\begin{array}{c}\text { metallic } \\
\text { haze }\end{array}$ & $\begin{array}{c}\text { metallic } \\
\text { haze }\end{array}$ & $\begin{array}{c}\text { metallic } \\
\text { haze }+ \\
\mathrm{SO}_{4}{ }^{=}\end{array}$ & $\mathrm{SO}_{4}{ }^{=}$ & $\mathrm{SO}_{4}{ }^{=}$ & $\mathrm{SO}_{4}=$ & $\mathrm{SO}_{4}{ }^{=}$ \\
\hline
\end{tabular}

clean = black and shiny glass

metallic haze $=$ presence of spinels across entire glass surface (not soluble)

$\mathrm{SO}_{4}{ }^{2}$ (yellow-shaded cell) $=$ presence of $\mathrm{SO}_{4}{ }^{2}$ - either on wall of crucible, along melt line, or sulfate haze on surface

\footnotetext{
2 The photos in Figure 2-1 are shown to present representations of how the glasses that had no sulfate present on the surface and the glasses with sulfate on the surface looked. Pictures from all other tests performed for this study are shown in Notebook WSRC-NB-2005-00004.
} 
In Table 2-3, the yellow cells indicate where $\mathrm{SO}_{4}{ }^{2}$ was observed on the surface (along the melt line) or on the crucible walls. Some crucibles also had a sulfur-scum layer on the surface. Some crucibles showed no indications of $\mathrm{SO}_{4}{ }{ }$ on the surface, but had a metallic haze over the surface, which indicates the presence of spinels. It should be mentioned that the presence of spinels (or the metallic haze) was more prevalent with the higher WL glasses which agrees with previous observations (Peeler et al., 2004a).

\subsubsection{Frit 418 Tests}

In general the sealed-crucible tests with Frit 418, which contains less total alkali than Frit 320, did not incorporate $\mathrm{SO}_{4}{ }^{2}$ in the glass to the extent the Frit 320 did. Visible evidence of sulfate was apparent at 0.5 wt $\% \mathrm{SO}_{4}{ }^{=}$in the $30 \%$ and $40 \%$ WL tests with Frit 418. A table of the visual observations of all the tests with Frit 418 appears in Table 2-3. Based on these test results of Frits 320 and 418 with the 1200canister, $2^{\text {nd }}$ transfer scenario for SB4, a scoping study was started to determine if Ca- or V-based frits would increase $\mathrm{SO}_{4}{ }^{2}$ solubility.

\subsection{0-Canister, $1^{\text {st }}$ Transfer Scenario}

It was stated that the current production plan was to combine SB4 with SB3 heel after the contract baseline equivalent canisters (1100) have been produced (Lilliston and Shah, 2004; Lilliston, 2005). The second series of tests was based on the 1100 -canister, $1^{\text {st }}$ transfer case for SB4 (from Lilliston, 2005). The elemental composition of SB4 for this 1100-canister scenario is listed in Table 2-4 (no $\mathrm{SO}_{4}{ }^{=}$levels reported).

Table 2-4. Elemental composition of SB4 sludge - 1100 -canister, $1^{\text {st }}$ transfer scenario

\begin{tabular}{|c|c|}
\hline Elementals & $\begin{array}{c}\text { 1100-Canister, } \\
\text { Transfer Baseline }\end{array}$ \\
\hline $\mathrm{Al}$ & 11.908 \\
\hline $\mathrm{B}$ & 0.000 \\
\hline $\mathrm{Ba}$ & 0.144 \\
\hline $\mathrm{Ca}$ & 1.584 \\
\hline $\mathrm{Ce}$ & 0.176 \\
\hline $\mathrm{Cr}$ & 0.171 \\
\hline $\mathrm{Cs}$ & 0.000 \\
\hline $\mathrm{Cu}$ & 0.066 \\
\hline $\mathrm{Fe}$ & 18.051 \\
\hline $\mathrm{K}$ & 0.844 \\
\hline $\mathrm{La}$ & 0.079 \\
\hline $\mathrm{Li}$ & 0.000 \\
\hline $\mathrm{Mg}$ & 1.162 \\
\hline $\mathrm{Mn}$ & 4.486 \\
\hline $\mathrm{Mo}$ & 0.000 \\
\hline $\mathrm{Na}$ & 16.214 \\
\hline $\mathrm{Nb}$ & 0.000 \\
\hline $\mathrm{Ni}$ & 2.896 \\
\hline $\mathrm{Pb}$ & 0.153 \\
\hline $\mathrm{Si}$ & 1.267 \\
\hline
\end{tabular}

${ }^{3}$ Although not documented in this report, several tests using the 1200-canister scenario were performed as a preliminary assessment of the impact of $\mathrm{CaO}$ and $\mathrm{V}_{2} \mathrm{O}_{5}$ additions on the $\mathrm{SO}_{4}{ }^{=}$solubility of SB4. Three frits were identified with the potential of improving $\mathrm{SO}_{4}{ }^{=}$solubility and were ultimately used in the 1100 -canister tests. 


\begin{tabular}{|c|c|}
\hline Th & 0.030 \\
\hline Ti & 0.013 \\
\hline $\mathrm{U}$ & 7.805 \\
\hline $\mathrm{Y}$ & 0.000 \\
\hline $\mathrm{Zn}$ & 0.102 \\
\hline $\mathrm{Zr}$ & 0.205 \\
\hline
\end{tabular}

The Th and $\mathrm{U}$ were removed from this recipe as well and all other components were renormalized for these tests. Three frits in addition to Frits 320 and 418 were tested with the 1100 -canister composition of SB4 - Frits 447, 448, and 449. The compositions of these frits are listed in Table 2-5 (Frits 320 and 418 are listed in Table 2-2).

Table 2-5. Compositions of Frits 447, 448, and 449

\begin{tabular}{||l|c|c|c||}
\hline \hline Oxide & Frit 447 & Frit 448 & Frit 449 \\
\hline $\mathrm{B}_{2} \mathrm{O}_{3}$ & 8 & 8 & 8 \\
\hline $\mathrm{Li}_{2} \mathrm{O}$ & 8 & 8 & 8 \\
\hline $\mathrm{Na}_{2} \mathrm{O}$ & 12 & 12 & 12 \\
\hline $\mathrm{SiO}_{2}$ & 69.5 & 71.5 & 70 \\
\hline $\mathrm{V}_{2} \mathrm{O}_{5}$ & 0.5 & 0.5 & 0 \\
\hline $\mathrm{CaO}$ & 2 & 0 & 2 \\
\hline
\end{tabular}

The sealed-crucible tests of this series targeted $\mathrm{SO}_{4}{ }^{\circ}$ levels in the glass of $0.5,0.6$, and $0.7 \mathrm{wt} \%$, at $30 \%$ and $40 \% \mathrm{WL}$. Each crucible was placed in a furnace set at $1150^{\circ} \mathrm{C}$ for 4 hours, visual observations were made once the crucibles were cool and the lids were removed, and the chemical compositions were measured to assess the retention of $\mathrm{SO}_{4}{ }^{-}$in the glass.

For the WLs and $\mathrm{SO}_{4}{ }^{\circ}$ levels tested, all Frit 320-based glasses were void of a $\mathrm{SO}_{4}{ }^{\circ}$ layer on the surface. All glasses at $40 \% \mathrm{WL}$ had a metallic haze on the surface, which indicates the presence of spinels not sulfate. Tests with Frit 418 however showed $\mathrm{SO}_{4}{ }^{=}$on the surface at $0.7 \mathrm{wt} \% \mathrm{SO}_{4}{ }^{\circ}, 30 \% \mathrm{WL}$ and at 0.6 wt $\% \mathrm{SO}_{4}{ }^{2}, 40 \% \mathrm{WL}$. For the same tests conducted with Frits 447, 448, and 449, all crucibles were clean of $\mathrm{SO}_{4}{ }^{\circ}$ on the surface of the glasses at both $30 \%$ and $40 \% \mathrm{WL}\left(0.5-0.7 \mathrm{wt} \% \mathrm{SO}_{4}{ }^{{ }^{\prime}}\right)$. The same metallic haze apparent in the 40\% WL crucibles of Frit 320 was also apparent in the 40\% WL tests of Frits 418, 447, 448, and 449.

Since no $\mathrm{SO}_{4}{ }^{2}$ was evident on the glass surfaces at $\mathrm{SO}_{4}{ }^{2}$ levels of $0.5-0.7 \mathrm{wt} \%$ with Frits 320, 447, 448, and 449 with the 1100 -canister scenario of SB4, $\mathrm{SO}_{4}{ }^{=}$levels in glass of 0.8 and 0.9 wt\% were tested with those frits at $30 \%$ and $40 \% \mathrm{WL}$. For the $30 \% \mathrm{WL}$ tests, no $\mathrm{SO}_{4}{ }^{=}$was seen on the glass surface for any of the frits at $0.8 \mathrm{wt} \% \mathrm{SO}_{4}{ }^{\circ}$, but Frits 320 and 447 showed evidence of $\mathrm{SO}_{4}{ }^{{ }^{2}}$ at the $0.9 \mathrm{wt} \% \mathrm{SO}_{4}{ }^{{ }}$level. However, all frits showed $\mathrm{SO}_{4}{ }^{=}$on the glass surface for the $40 \% \mathrm{WL}$ tests at the $0.8 \mathrm{wt} \% \mathrm{SO}_{4}{ }^{=}$level (again, higher $\mathrm{Al}_{2} \mathrm{O}_{3}$ content may suppress $\mathrm{SO}_{4}{ }^{=}$solubility). A summary of all tests of the 1100 -canister, $1^{\text {st }}$ transfer scenario of SB4 is shown in Table 2-6, and the measured $\mathrm{SO}_{4}{ }^{{ }^{2}}$ compositions (in glass) for all tests are listed in Table 2-7. 
Table 2-6. Summary of closed-crucible tests for the 1100 -canister, $1^{\text {st }}$ transfer scenario

\begin{tabular}{|c|c|c|c|c|c|c|}
\hline Frit & $\overline{W L}$ & $\begin{array}{c}0.5 \mathrm{wt} \% \\
\mathrm{SO}_{4}={ }^{=} \text {target }\end{array}$ & $\begin{array}{c}0.6 \mathrm{wt} \% \\
\mathrm{SO}_{4}{ }^{=} \text {target }\end{array}$ & $\begin{array}{c}0.7 \mathrm{wt} \% \\
\mathrm{SO}_{4}{ }^{=} \text {target }\end{array}$ & $\begin{array}{c}0.8 \mathrm{wt} \% \\
\text { SO }_{4}{ }^{=} \text {target }\end{array}$ & $\begin{array}{c}0.9 \mathrm{wt} \% \\
\text { SO }_{4}=\text { target }\end{array}$ \\
\hline \multirow[t]{2}{*}{320} & $30 \%$ & clean & clean & clean & clean & $\mathrm{SO}_{4}=$ \\
\hline & $40 \%$ & metallic haze & metallic haze & metallic haze & $\mathrm{SO}_{4}{ }^{=}$ & $\mathrm{SO}_{4}{ }^{=}$ \\
\hline \multirow[t]{2}{*}{418} & $30 \%$ & clean & clean & $\mathrm{SO}_{4}{ }^{=}$ & --- & --- \\
\hline & $40 \%$ & metallic haze & $\mathrm{SO}_{4}{ }^{=}$ & $\mathrm{SO}_{4}=$ & --- & --- \\
\hline \multirow[t]{2}{*}{447} & $30 \%$ & clean & clean & clean & clean & $\mathrm{SO}_{4}{ }^{=}$ \\
\hline & $40 \%$ & metallic haze & metallic haze & metallic haze & $\mathrm{SO}_{4}{ }^{=}$ & $\mathrm{SO}_{4}{ }^{=}$ \\
\hline \multirow[t]{2}{*}{448} & $30 \%$ & clean & clean & clean & clean & clean \\
\hline & $40 \%$ & metallic haze & metallic haze & metallic haze & $\mathrm{SO}_{4}=$ & $\mathrm{SO}_{4}=$ \\
\hline \multirow[t]{2}{*}{449} & $30 \%$ & clean & clean & clean & clean & clean \\
\hline & $40 \%$ & metallic haze & metallic haze & metallic haze & $\mathrm{SO}_{4}{ }^{=}$ & $\mathrm{SO}_{4}{ }^{=}$ \\
\hline
\end{tabular}

clean = black and shiny glass

metallic haze $=$ presence of spinels across entire glass surface (not soluble)

$\mathrm{SO}_{4}{ }^{=}$(yellow-shaded cell) $=$presence of $\mathrm{SO}_{4}{ }^{=}-$either on wall of crucible, along melt line, or sulfate haze on surface

Table 2-7. Measured $\mathrm{SO}_{4}{ }^{=}$compositions (in glass) of studies for the 1100 -canister, $1^{\text {st }}$ transfer scenario

\begin{tabular}{|c|c|c|c|c|c|c|}
\hline & & \multicolumn{5}{|c|}{ Measured $\mathrm{SO}_{4}{ }^{=}$composition (in glass) at specified $\mathrm{SO}_{4}{ }{ }^{2}$ target } \\
\hline Frit & WL & $\begin{array}{c}0.5 \mathrm{wt} \% \\
\mathrm{SO}_{4}=\text { target }\end{array}$ & $\begin{array}{c}0.6 \mathrm{wt} \% \\
\mathrm{SO}_{4}{ }^{=} \text {target }\end{array}$ & $\begin{array}{c}0.7 \mathrm{wt} \% \\
\mathrm{SO}_{4}{ }^{=} \text {target }\end{array}$ & $\begin{array}{c}0.8 \mathrm{wt} \% \\
\mathrm{SO}_{4}{ }^{=} \text {target }\end{array}$ & $\begin{array}{c}0.9 \mathrm{wt} \% \\
\mathrm{SO}_{4}{ }^{=} \text {target }\end{array}$ \\
\hline \multirow[t]{2}{*}{320} & $30 \%$ & 0.470 & 0.563 & 0.646 & 0.770 & 0.878 \\
\hline & $40 \%$ & 0.505 & 0.569 & 0.683 & 0.836 & 0.897 \\
\hline \multirow[t]{2}{*}{418} & $30 \%$ & 0.442 & 0.578 & 0.614 & --- & --- \\
\hline & $40 \%$ & 0.492 & 0.566 & 0.595 & --- & --- \\
\hline \multirow[t]{2}{*}{447} & $30 \%$ & 0.474 & 0.590 & 0.673 & 0.765 & 0.783 \\
\hline & $40 \%$ & 0.474 & 0.595 & 0.635 & 0.770 & 0.854 \\
\hline \multirow[t]{2}{*}{448} & $30 \%$ & 0.490 & 0.599 & 0.668 & 0.729 & 0.790 \\
\hline & $40 \%$ & 0.490 & 0.621 & 0.703 & 0.754 & 0.827 \\
\hline \multirow[t]{2}{*}{449} & $30 \%$ & 0.506 & 0.569 & 0.692 & 0.751 & 0.850 \\
\hline & $40 \%$ & 0.515 & 0.606 & 0.697 & 0.787 & 0.891 \\
\hline
\end{tabular}

Each glass was measured in duplicate. The reported value is the average $\mathrm{SO}_{4}{ }^{*}$ composition (in glass).

As stated earlier, testing for this study was performed with sealed crucibles in order to inhibit sulfate vaporization and to increase $\mathrm{SO}_{4}{ }{ }$ retention to the maximum extent possible. For the $0.5 \mathrm{wt} \% \mathrm{SO}_{4}{ }^{{ }^{2}}$ target column of Table 2-7, all measured $\mathrm{SO}_{4}{ }{ }$ concentrations hit the target (within $\sim 0.03 \mathrm{wt} \% \mathrm{SO}_{4}{ }^{{ }}$) with the exception of Frit 418 at $30 \% \mathrm{WL}$, and no $\mathrm{SO}_{4}{ }^{\circ}$ was observed. The first test where $\mathrm{SO}_{4}{ }^{\circ}$ was observed on the surface was Frit 418 at $40 \% \mathrm{WL}$ at a $\mathrm{SO}_{4}{ }{ }$ target of $0.6 \mathrm{wt} \%$. However, at the same $\mathrm{SO}_{4}{ }{ }$ target similar $\mathrm{SO}_{4}{ }^{=}$concentrations were measured for Frit 320 (30\% and 40\% WL) and Frit 449 (30\% WL), yet no $\mathrm{SO}_{4}{ }^{=}$was observed on the glass surface. At a $\mathrm{SO}_{4}{ }^{=}$target of $0.6 \mathrm{wt} \%$, all the measured concentrations were within $\sim \pm 0.03 \mathrm{wt} \%$ of their targeted values. This observation suggests very little, if any, volatility. It should be noted that $\mathrm{SO}_{4}{ }{ }$ was observed on the surface of the Frit 418 at $40 \%$ WL glass even though the measured $\mathrm{SO}_{4}{ }{ }$ concentration is within the assumed $0.03 \mathrm{wt} \%$ analytical uncertainty (which is relatively consistent with the $\pm 0.02 \mathrm{wt} \% \mathrm{SO}_{4}{ }{ }$ measurement uncertainty noted by Peeler et al. (2004a)). At a $\mathrm{SO}_{4}{ }^{=}$ target of $0.7 \mathrm{wt} \%, 6$ of the 10 glasses measured $\mathrm{SO}_{4}{ }{ }^{2}$ concentrations within $\sim \pm 0.03 \mathrm{wt} \%$ of their targeted values. The exceptions were Frit 320 at 30\% WL, Frit 418 at 30\% WL, Frit 418 at 40\% WL, and Frit 447 at $40 \% \mathrm{WL}$. $\mathrm{SO}_{4}{ }{ }$ was observed on the glass surface in the Frit 418 tests ( $30 \%$ and $40 \% \mathrm{WL}$ ), so the measured values are consistent with expectations that both glasses were well below the target (i.e., $>0.09 \%$ below the $0.7 \mathrm{wt} \%$ target). $\mathrm{No} \mathrm{SO}_{4}{ }{ }$ was observed on the glass surface of the Frit 447 at $40 \%$ 
WL or the Frit 320 at $30 \% \mathrm{WL}$ (both targeting $0.7 \mathrm{wt} \% \mathrm{SO}_{4}{ }^{{ }^{\circ}}$ ) though, and the measured $\mathrm{SO}_{4}{ }^{=}$ concentrations in the glasses were 0.635 and $0.646 \mathrm{wt} \%$, respectively. Coupling the visual observations with the analytical results does suggest a batching issue, more volatility (in some cases), and/or larger analytical uncertainty than observed in previous $\mathrm{SO}_{4}{ }{ }$ solubility tests (Peeler et al., 2004a). Other discrepancies are evident in the 0.8 and $0.9 \mathrm{wt}^{2} \mathrm{SO}_{4}{ }^{\circ}$ target tests as well - Frit 320 at $30 \%$ and $40 \% \mathrm{WL}$ (0.9 wt\% SO ${ }_{4}{ }$ target), Frit 320 at $40 \% \mathrm{WL}\left(0.8 \mathrm{wt} \% \mathrm{SO}_{4}{ }^{{ }^{2}}\right.$ target), Frit 447 at $40 \% \mathrm{WL}\left(0.8 \mathrm{wt} \% \mathrm{SO}_{4}{ }^{{ }^{\prime}}\right.$ target), and Frit 449 at $40 \% \mathrm{WL}\left(0.8\right.$ and $0.9 \mathrm{wt} \% \mathrm{SO}_{4}{ }{ }$ target). If the DWPF limit for SB4 were to be set using this data as a basis, the more conservative measured values would be used versus the targets to provide a comfortable margin of error that sulfate was not going to form. Peeler et al. (2004a) used an equivalent experimental approach in setting the DWPF $\mathrm{SO}_{4}{ }^{=}$limit for SB3-Frit 418. Even with the discrepancy in measured values, the results confirm that there are frit/sludge systems available to retain at least $0.6 \mathrm{wt} \% \mathrm{SO}_{4}{ }{ }$ without the formation of a salt layer.

\subsection{DISCUSSION}

The election to test the 1200 -canister, $2^{\text {nd }}$ transfer case for SB4 first in this suite of sulfate-solubility tests was based on this being the most conservative blending scenario of SB4 with the heel of SB3 for $\mathrm{SO}_{4}{ }^{=}$ solubility - highest viscosity would provide lowest $\mathrm{SO}_{4}{ }^{\prime}$ solubility. The decision to utilize Frits 320 and 418 in the testing was based on the fact that the DWPF has processed with those frits before and on the preliminary model-based assessments performed by Peeler and Edwards (2005a) - Frit 320 and 418 had WL operating windows from $25 \%$ to $43 \% \mathrm{WL}$. The tests showed that at the DWPF's current $\mathrm{SO}_{4}{ }^{=}$limit (in glass), $0.6 \mathrm{wt} \%$, and the tested WLs (30\% and 40\%), neither Frit 320 nor Frit 418 would provide the most flexibility for processing of SB4 (for the 1200-canister, $2^{\text {nd }}$ transfer case) if the projected sludge $\mathrm{SO}_{4}{ }^{\prime}$ concentrations are valid. Therefore, other options were pursued to provide the flexibility and to support meeting accelerated mission objectives.

Since lowering the current $\mathrm{SO}_{4}{ }$ limit in the DWPF for SB4 processing is not the preferred option to support accelerated closure, new frits were developed to try to enhance the sludge batch's sulfate solubility. With the addition of $\mathrm{CaO}$ and/or $\mathrm{V}_{2} \mathrm{O}_{5}$ to Frit $320^{4}$, Frits 447, 448, and 449 were developed. Recent studies have suggested that $\mathrm{CaO}$ and $\mathrm{V}_{2} \mathrm{O}_{5}$ additions to borosilicate formulations improve sulfur solubility in the melt (Stefanovsky and Lifanov, 1990; McKeown et al., 2002; Vienna et al., 2002). With the 1100-canister, $1^{\text {st }}$ transfer composition for SB4 (from Lilliston, 2005), the sealed-crucible studies with Frits 447, 448, and 449 showed the frits enhance the $\mathrm{SO}_{4}{ }^{2}$ solubility for SB4 - all crucibles were clear of the "yellow" up to $0.7 \mathrm{wt} \% \mathrm{SO}_{4}{ }^{2}$. Also, all tests conducted with the 1100 -canister, $1^{\text {st }}$ transfer composition of SB4 with Frit 320 up to $0.7 \mathrm{wt} \% \mathrm{SO}_{4}{ }^{~}{ }$ were clean of $\mathrm{SO}_{4}{ }^{-}$on the surface. Experimentally, the additions of $\mathrm{CaO}$ and $\mathrm{V}_{2} \mathrm{O}_{5}$ to the frit - Frits 447, 448, and 449 - did not appear to greatly enhance $\mathrm{SO}_{4}{ }^{=}$solubility for SB4 over Frit 320.

In 2004, the sulfate solubility limit for the DWPF was revised (Peeler et al., 2004a) - raised from 0.4 wt\% to $0.6 \mathrm{wt} \% \mathrm{SO}_{4}{ }^{2}$. Jantzen and Smith (2004) recommended that the predicted levels of sulfate solubility be calculated via Equation 1:

$$
\mathrm{SO}_{4}{ }^{=} \text {solubility (at saturation) }=1.5333-0.5585 \log \text { viscosity }{ }_{\text {calc }} \text { (poise) }
$$

\section{Equation 1}

\footnotetext{
${ }^{4}$ Frits 447, 448, and 449 were developed from Frit 320 since it had the higher $\mathrm{Na}_{2} \mathrm{O}$ content (versus Frit 418) and were shown to have a higher $\mathrm{SO}_{4}{ }^{=}$solubility. The amounts of $\mathrm{B}_{2} \mathrm{O}_{3}, \mathrm{Li}_{2} \mathrm{O}$, and $\mathrm{Na}_{2} \mathrm{O}$ were kept the same as Frit 320 while the flux $\mathrm{SiO}_{2}$ was reduced by the additions of the $\mathrm{CaO}$ and $\mathrm{V}_{2} \mathrm{O}_{5}$ (see Table 2-2 and Table 2-5).
} 
Equation 1 will allow a $\mathrm{SO}_{4}{ }^{\circ}$ solubility of $0.81 \mathrm{wt} \%$ at the DWPF lower viscosity limit of 20 poise, a $\mathrm{SO}_{4}{ }^{=}$ solubility of $0.39 \mathrm{wt} \%$ at the DWPF upper viscosity limit of 110 poise, and a $\mathrm{SO}_{4}{ }^{\overline{ }}$ solubility of $0.58 \mathrm{wt} \%$ at an average viscosity of 50 poise. The predicted viscosities and approximated $\mathrm{SO}_{4}{ }^{=}$solubilities in glass (at saturation) of each tested frit with the 1100-canister baseline are shown in Table 3-1.

Table 3-1. Approximated $\mathrm{SO}_{4}{ }^{=}$solubilities (at saturation) of tested frits with the 1100 -canister, $1^{\text {st }}$ transfer baseline scenario

\begin{tabular}{||c|c|c|c||}
\hline Frit & WL & Viscosity ${ }_{\text {calc }}$ (poise) & SO $_{\mathbf{4}}{ }^{{ }^{\prime}}$ limit (at saturation) \\
\hline 320 & $30 \%$ & 43.340 & 0.62 \\
\hline & $40 \%$ & 29.317 & 0.71 \\
\hline 418 & $30 \%$ & 75.186 & 0.48 \\
\hline & $40 \%$ & 51.650 & 0.58 \\
\hline 447 & $30 \%$ & 37.915 & 0.65 \\
\hline & $40 \%$ & 25.330 & 0.75 \\
\hline 448 & $30 \%$ & 42.227 & 0.62 \\
\hline & $40 \%$ & 28.495 & 0.72 \\
\hline 449 & $30 \%$ & 38.972 & 0.65 \\
\hline & $40 \%$ & 26.103 & 0.74 \\
\hline
\end{tabular}

The predicted $\mathrm{SO}_{4}{ }{ }$ solubility limits listed in Table 3-1 confirm what was shown by the closed-crucible experiments conducted for this study - the trend for the $\mathrm{SO}_{4}{ }^{2}$ limit of SB4 (1100-canisters) is Frit 320 Frit $447 \approx$ Frit $448 \approx$ Frit $449>$ Frit 418 . However, the viscosity model developed by Jantzen and Smith (2004) does not include $\mathrm{V}$ when calculating the $\mathrm{SO}_{4}{ }^{\circ}$ solubility limit for the DWPF.

\subsection{CONCLUSIONS}

The current production plan for the DWPF is to blend SB4 with SB3 heel after the contract baseline equivalent canisters (1100) have been produced (Shah et al., 2005). The initial investigations of this study have indicated that the current $\mathrm{SO}_{4}{ }^{=}$solubility limit in the DWPF of $0.6 \mathrm{wt} \%$, established by Peeler et al. (2004a) for the Frit 418 - SB3 system, can be applicable and possibly be raised for the 1100canister, $1^{\text {st }}$ transfer case of SB4 (tested $30 \%$ and $40 \% \mathrm{WL}$ ). Five frits were tested in closed-crucible studies - Frits $320,418,447,448$, and 449. At the current $\mathrm{SO}_{4}{ }^{=}$solubility limit in the DWPF, the use of Frit 418 has the potential to limit the $\mathrm{WL}$ for $\mathrm{SB} 4$, as the presence of $\mathrm{SO}_{4}{ }^{=}$was apparent on the glass surface of tests at $40 \% \mathrm{WL}$ and $0.6 \mathrm{wt} \% \mathrm{SO}_{4}{ }^{2}$. No $\mathrm{SO}_{4}{ }^{=}$was evident though in any test with Frits 320 , 447,448 , or 449 until a $0.8 \mathrm{wt} \% \mathrm{SO}_{4}{ }{ }^{2}$ concentration was reached. The crucible tests of this study and model predictions (from Jantzen and Smith, 2004) indicated that the $\mathrm{SO}_{4}{ }^{*}$ solubility limit for SB4 with those four frits would be similar. However, even with the additions of $\mathrm{Ca}$ and $\mathrm{V}$ (as suggested by previous studies), the solubility of $\mathrm{SO}_{4}{ }^{2}$ was not greatly enhanced by Frits 447, 448, and 449 over Frit 320 for the 1100 -canister, $1^{\text {st }}$ transfer case.

This suite of sulfate-solubility tests began by testing the 1200 -canister, $2^{\text {nd }}$ transfer case for SB 4 - this was based on this being the most conservative (based on predicted viscosity) blending scenario of SB4 with the heel of SB3 at the time. The $\mathrm{SO}_{4}{ }^{=}$solubility limit of Frit 320 and 418 for the 1200 -canister, $2^{\text {nd }}$ transfer case of SB4 for this set of projections would be $0.5 \mathrm{wt} \%$ and $0.4 \mathrm{wt} \%$, respectively, and since lowering the current $\mathrm{SO}_{4}{ }^{=}$solubility limit in the DWPF is not the preferred option for meeting accelerated mission efforts or for providing operating flexibility, new frits were developed. 


\subsection{RECOMMENDATIONS/PATH FORWARD}

The following recommendation is made regarding the $\mathrm{SO}_{4}{ }^{=}$solubility limit for SB4 in the DWPF:

- Reinvestigate the solubility of $\mathrm{SO}_{4}{ }^{=}$for $\mathrm{SB} 4$ once the final blending and/or washing strategies for SB4 are determined - based on the decisions for the inclusion of Tank 4 and the exact volume and composition of the $\mathrm{Np}$ stream - in order to determine if the current $\mathrm{SO}_{4}{ }^{2}$ solubility limit $(0.6$ $\mathrm{wt} \% \mathrm{SO}_{4}{ }^{=}$) in the DWPF needs to be increased for the processing of SB4. 


\subsection{REFERENCES}

Bickford, D.F. and C.M. Jantzen. 1986. Inhibitor Limits for Washed Precipitate Based on Glass Quality and Solubility Limits, U.S. DOE Report DPST-86-546, E.I. DuPont deNemours \& Co., Savannah River Laboratory, Aiken, South Carolina.

Bickford, D.F., A. Applewhite-Ramsey, C.M. Jantzen, and K.G. Brown. 1990. "Control of Radioactive Waste Glass Melters: I, Preliminary General Limits at Savannah River,” J. Am. Ceram. Soc, 73 [10], pp. 2896-2902.

Brown, K.G., R.L. Postles, and T.B. Edwards. 2002. SME Acceptability Determination for DWPF Process Control, WSRC-TR-95-0364, Rev. 4, Westinghouse Savannah River Company, Aiken, South Carolina.

Jantzen, C.M. and M.E. Smith. 2004. Revision of the Defense Waste Processing Facility (DWPF) Sulfate Solubility Limit (U), WSRC-TR-2003-00518, Rev. 0, Westinghouse Savannah River Company, Aiken, South Carolina.

Jantzen, C.M., M.E. Smith, and D.K. Peeler. 2004. "Dependency of Sulfate Solubility on Melt Composition and Melt Polymerization,” in Ceramic Transactions, Vol. 168, pp. 141-152, The American Ceramic Society, Westerville, Ohio.

Lilliston, G.R. 2005. Development of Elemental Sludge Compositions for Variations for Sludge Batch 4 (SB4), CBU-PIT-2004-00011, Rev. 1, Westinghouse Savannah River Company, Aiken, South Carolina.

Lilliston, G.R. and H.H. Elder. 2003. Disposal Strategy and Path Forward for Effluents from the HCanyon Np Stabilization Campaign, CBU-PED-2003-00030, Rev. 0, Westinghouse Savannah River Company, Aiken, South Carolina.

Lilliston, G.R. and H.B. Shah. 2004. Development of Elemental Sludge Compositions for Variations for Sludge Batch 4 (SB4), CBU-PIT-2004-00011, Rev. 0, Westinghouse Savannah River Company, Aiken, South Carolina.

McKeown, D.A., I.S. Muller, K.S. Matlack, and I.L. Pegg. 2002. "X-ray absorption studies of vanadium valence and local environment in borosilicate waste glasses using vanadium sulfide, silicate, and oxide standards,” Journal of Non-Crystalline Solids, 298, pp. 160-175.

Peeler, D.K., C.C. Herman, M.E. Smith, T.H. Lorier, D.R. Best, T.B. Edwards, and M.A. Baich. 2004a. An Assessment of the Sulfate Solubility Limit for the Frit 418 - Sludge Batch 2/3 System, WSRC-TR2004-00081, Rev. 0, Westinghouse Savannah River Company, Aiken, South Carolina.

Peeler, D.K. et al. 2004b. Sludge Batch 4 and MCU Frit Optimization, WSRC-RP-2004-00746, Rev. 0, Westinghouse Savannah River Company, Aiken, South Carolina.

Peeler, D.K. and T.B. Edwards. 2005a. Frit Development for SB4 - Assessments of Initial Sludge Options (Set \#1), SRNL-GPD-2005-00023, Westinghouse Savannah River Company, Aiken, South Carolina.

Peeler, D.K. and T.B. Edwards. 2005. Frit Development Efforts for Sludge Batch 4 (SB4): Model-Based Assessments, WSRC-TR-2005-00103, Westinghouse Savannah River Company, Aiken, South Carolina. 
Schumacher, R.F., M.E. Smith, and J.F. Sproull. 1991. Review of Background Applicable to the Potential for a Steam Explosion in the DWPF Melter, WSRC-RD-91-15, Westinghouse Savannah River Company, Aiken, South Carolina.

Shah, H.B., G.R. Lilliston, and J.M. Gillam. 2005. Preliminary Blending, Washing, Additions, Feed and Glass Qualification Strategies for the Combination of Sludge Batch 4 (Tanks 4, 5, 6, 8, and 11) with Sludge Batch 3 as Feed into DWPF, CBU-PIT-2004-00021, Westinghouse Savannah River Company, Aiken, South Carolina.

Stefanovsky, S.V. and F.A. Lifanov. 1990. "Glasses for Immobilization of Sulfate-Containing Radioactive Wastes,” Radiokhimiya, 32[6], pp. 129-134.

Sullivan, G.K., M.H. Langowski, and P. Hrma. 1995. "Sulfate Segregation in Vitrification of Simulated Hanford Nuclear Waste,” J. Am. Ceram. Soc, 61, pp. 187-193.

Vienna, J.D., W.C. Buchmiller, J.V. Crum, D.D. Graham, D.S. Kim, B.D. MacIsaac, M.J. Schweiger, D.K. Peeler, T.B Edwards, I.A. Reamer, and R.J. Workman. 2002. Glass Formulation Development for INEEL Sodium-Bearing Waste. PNNL-14050, Pacific Northwest National Laboratory, Richland, WA 99352. 


\section{Distribution:}

E.W. Holtzscheiter, 773-A

D.A. Crowley, 999-W

S.L. Marra, 999-W

T.B. Calloway, 999-W

N.E. Bibler, 773-A

C.M. Jantzen, 773-A

J.R. Harbour, 773-42A

G.G. Wicks, 773-A

D.K. Peeler, 999-W

T.B. Edwards, 773-42A

C.C. Herman, 773-42A

T.H. Lorier, 773-A

M.E. Smith, 773-42A

M.E. Stone, 999-W

A.S. Choi, 773-42A

D.C. Bumgardner, 766-H

M.S. Miller, 704-S

J.E. Occhipinti, 704-S

R.M. Hoeppel, 704-27S

H.H. Elder, 703-H

J.M. Gillam, 766-H

J.F. Iaukea, 704-30S

J.W. Ray, 704-S

H.B. Shah, 766-H

F.A. Washburn, 704-28S

A.B. Sanders, 704-27S

W.B. Van-Pelt, 704-S 